\title{
Reactions in the Annual Medicago spp. Core Germ Plasm Collection to Phoma medicaginis
}

Nichole R. O'Neill and Gary R. Bauchan, USDA-ARS, Beltsville, MD 20705; and Deborah A. Samac, USDAARS, University of Minnesota, St. Paul 55108

\section{ABSTRACT}

O’Neill, N. R., Bauchan, G. R., and Samac, D. A. 2003. Reactions in the annual Medicago spp. core germ plasm collection to Phoma medicaginis. Plant Dis. 87:557-562.

The annual Medicago spp. core collection, consisting of 201 accessions, represents the genetic diversity inherent in 3,159 accessions from 36 annual Medicago spp. This germ plasm was evaluated for resistance to spring black stem and leaf spot caused by Phoma medicaginis. Spring black stem and leaf spot is a major destructive disease in perennial alfalfa (Medicago sativa) grown in North America, Europe, and other temperate regions. Disease control is based principally on the use of cultivars with moderate levels of resistance. Evaluation of the core collection was conducted using standardized environmental conditions in growth chambers, and included the $M$. sativa standard reference cultivars Ramsey (resistant) and Ranger (susceptible). The degree of resistance found among accessions within species was variable, but most annual species and accessions were susceptible. Most accessions from 10 species exhibited high disease resistance. These included accessions of M. constricta, M. doliata, M. heyniana, M. laciniata, M. lesinsii, M. murex, M. orbicularis, M. praecox, M. soleirolii, and M. tenoreana. Most of the accessions within M. arabica, M. minima, M. lanigera, M. rotata, M. rugosa, M. sauvagei, and $M$. scutellata were highly susceptible. Disease reactions among some accessions within species were highly variable. On a 0 -to- 5 disease severity scale, ratings ranged from 0.67 (PI 566873 ) to 4.29 (PI 566883) within accessions of M. polymorpha. Most of the M. truncatula accessions were susceptible, with a mean of 3.74. Resistant reactions were similar to those found in incompatible interactions with $P$. medicaginis and alfalfa, which have been associated with specific genes leading to the production of isoflavonoid phytoalexins. The large genetic variability in annual Medicago spp. offers potential for locating and utilizing disease resistance genes through breeding or genetic engineering that will enhance the utilization of Medicago spp. as a forage crop.

Additional keywords: alfalfa, disease resistance, lucerne
Recent interest in the use of annual species of Medicago as a cover and forage crop for use in sustainable agriculture systems in the United States has prompted both an evaluation of the diversity of germ plasm that exists and the development of an annual Medicago spp. (medics) core collection. This collection represents the genetic diversity inherent in 3,159 accessions from 36 species of annual Medicago contained in the United States National Plant Germplasm System (10,12). A subset of 1,240 accessions was evaluated for morphological and agronomic traits, and accessions were chosen within a species to represent the greatest diversity in geographical origin (11). The selected core collection of 201 accessions from 33 spe-

Corresponding author: Nichole O'Neill

Accepted for publication 17 December 2002.

This article is in the public domain and not copyrightable. It may be freely reprinted with customary crediting of the source. The American Phytopathological Society, 2003.
E-mail: oneilln@ba.ars.usda.gov

Publication no. D-2003-0314-01R cies was evaluated at seven locations across the United States, and found to remain stable across environments and to represent the variability of the germ plasm collection (11). Annual medics have potential use in North America as weed-suppressing smother crops, cover crops in row crop production, and for short-season forage crops $(5,15)$.

Annual Medicago spp. are native to regions surrounding the Mediterranean Sea, and commercial cultivars are important forage crops in Australia and South Africa. The species that are most widely grown and from which commercial cultivars have been developed are $M$. littoralis, M. murex, M. polymorpha, M. rugosa, M. scutellata, and $M$. truncatula (5). Foliar diseases frequently occur in these species and cause significant yield losses $(1-3,24)$. The same foliar diseases cause significant losses in forage and seed yield in $M$. sativa $(30,32,34)$. The availability of disease-resistant accessions in the annual medic collection will enhance the utilization of these species in North American agro-ecosystems, and also may serve as a potential source of new or novel resistance genes amenable for incorporation into adapted genotypes.

Sources of resistance in annual Medicago spp. to one of the most important indigenous foliar diseases of alfalfa, anthracnose caused by Colletotrichum trifolii Bain \& Essary, have been reported $(23,26)$.
Table 1. Virulence of Phoma medicaginis isolates to Medicago sativa cultivar Ranger

\begin{tabular}{lllc}
\hline P. medicaginis isolate & \multicolumn{1}{c}{ Origin } & \multicolumn{1}{c}{ Host } & Disease severity $^{\mathbf{a}}$ \\
\hline P198 & Canada & M. sativa & 2.4 \\
P298 & Aichi, Japan & M. lupulina & 3.6 \\
P398 & Montpellier, France & M. truncatula & 2.7 \\
P598 & Sweden & M. sativa & 3.9 \\
P798 & Battle Ground, IN & M. sativa & 4.7 \\
P1598 (T-430) & Tucson, AZ & M. sativa & 4.1 \\
P1698 (T-432) & Tucson, AZ & M. sativa & 3.9 \\
P1798 (T-431) & Tucson, AZ & M. sativa & 4.0 \\
P1998 (5D85-8) & Pullman, WA & Unknown & 3.4 \\
1585 & State College, PA & M. sativa & 4.5 \\
647 & State College, PA & M. sativa & 3.6 \\
979 & Bucks Co. PA & M. sativa & 4.7 \\
866 & Wisconsin & M. sativa & 4.7 \\
1065 & State College, PA & M. sativa & 4.0 \\
W13 & West Madison, WI & M. sativa & 2.6 \\
W2 & West Madison, WI & M. sativa & 3.6 \\
WA2 & Wisconsin & M. sativa & 3.2 \\
PACRS1 & Wisconsin & M. sativa & 4.4 \\
PA2453 & Wisconsin & M. sativa & 3.5 \\
LSD & .. & .. & 0.7 \\
\hline
\end{tabular}

a Data represents means from six pots from two experiments that were combined for analysis. Plants were evaluated on a 0 -to-5 scale, where $0=$ healthy, symptom-free top growth; $1=$ small $(<2 \mathrm{~mm})$, brown or black lesions or flecks; no defoliation; $2=\operatorname{larger}(2$ to $3 \mathrm{~mm}$ ), discrete lesions; lesions may be on leaves and petioles; usually no chlorosis or defoliation; $3=$ large $(>3 \mathrm{~mm})$ lesions; no defoliation; petiole lesions; 4 = lesions $>3 \mathrm{~mm}$; chlorosis, dead leaves, or defoliation; and $5=$ most of the leaves necrotic or defoliated; dead plant.

b Least significant difference (LSD) was calculated according to Fisher's protected test at $P \leq 0.05$. 
DeHaan et al. (9) were the first to report the existence of Phytophthora root rot on annual medics, and they found that most cultivars and accessions within eight annual medic species were susceptible. Recent evaluations of reactions in this collection to powdery mildew caused by Erysiphe pisi DC. and downy mildew caused by Peronospora trifoliorum de Bary revealed a wide range of disease reactions $(35,36)$. Economically important diseases for which evaluations have not been made include spring black stem and leaf spot caused by Phoma medicaginis (Malbr. \& Roum.) var. medicaginis Boerema (syn. $P$. herbarum Westend. var. medicaginis Fckl. and Ascochyta imperfecta Peck), and Leptosphaerulina leaf spot caused by Leptosphaerulina briosiana (Pollacci) J. H. Graham \& Luttrell $(1,2,23,29,32)$.

Spring black stem and leaf spot caused by $P$. medicaginis is a common and often serious disease in North America and Europe. It is characterized by premature leaf drop; stem, leaf, and petiole necrosis; and crown and root rot of mature plants (32). Losses in yield and quality can be high, and cultivars with acceptable levels of resistance are not available (28). In a survey of foliage diseases on 42 accessions of annual Medicago spp. in South Africa, spring black stem and leaf spot was the most common of nine diseases recorded on aboveground plant parts (24). Disease control is based principally on the use of a few moderately resistant cultivars, early cutting to reduce leaf loss, and fungicides (32,34). Another species of Phoma, P. sclerotioides, the cause of brown root rot, has recently been reported on alfalfa in the United States (21).

Defense reactions to $P$. medicaginis have been associated with the production of pterocarpan and isoflavonoid phytoalexins following infection $(13,19,27)$. Fungitoxic phenolic compounds have been identified from several annual Medicago spp., but their role in disease resistance has not been investigated (22). Annual Medicago spp. exhibiting disease resistance may contain novel disease resistance genes or produce fungitoxic secondary metabolites that could be exploited for use in adapted perennial alfalfa via genetic engineering. Modifying flavonoids has been shown to increase disease resistance in alfalfa $(18,20,27)$.

Alfalfa is an autotetraploid that suffers from inbreeding depression, resulting in self-sterile accessions after a few generations of self-pollination. Cultivars are very heterogeneous and usually are developed as synthetics. Because most annual medics are diploids $(2 n=14$ or 16$)$, autogamous, and self-fertile, these species are genetically simpler to study and easier to manipulate than alfalfa. Some species, such as M. truncatula, are transformable $(7,33)$ and are being used as a model legume system $(6,8)$, to study symbiosis-related plant
Table 2. Evaluation of the annual Medicago core collection for resistance to spring black stem and leaf spot caused by Phoma medicaginis

\begin{tabular}{|c|c|c|}
\hline Medicago spp. and PI number ${ }^{\mathrm{a}}$ & Country of origin & Disease severity $^{\mathbf{b}}$ \\
\hline \multicolumn{3}{|l|}{ arabica } \\
\hline PI 495200 & France & 4.00 \\
\hline PI 495212 & Hungary & 4.00 \\
\hline Mean & & 4.00 \\
\hline \multicolumn{3}{|l|}{ blancheana } \\
\hline PI 495215 & Unknown & 1.33 \\
\hline PI 495216 & Turkey & 2.33 \\
\hline PI 495222 & Lebanon & 1.33 \\
\hline PI 495223 & Lebanon & 2.33 \\
\hline PI 495227 & Hungary & 2.33 \\
\hline PI 505415 & Spain & 1.83 \\
\hline PI 505416 & Spain & 2.33 \\
\hline Mean & & 1.97 \\
\hline \multicolumn{3}{|l|}{ ciliaris } \\
\hline PI 368928 & USA (California) & 2.67 \\
\hline PI 442645 & Turkey & 2.17 \\
\hline PI 498731 & Czechoslovakia & 2.17 \\
\hline PI 498750 & Lebanon & 2.17 \\
\hline PI 498784 & Tunisia & 2.50 \\
\hline PI 498785 & Morocco & 2.67 \\
\hline Mean & & 2.39 \\
\hline \multicolumn{3}{|l|}{ constricta } \\
\hline PI 495240 & Greece & 1.71 \\
\hline PI 534177 & Bulgaria & 2.00 \\
\hline PI 534182 & Cyprus & 1.83 \\
\hline Mean & & 1.85 \\
\hline \multicolumn{3}{|l|}{ coronata } \\
\hline PI 498790 & Greece & 2.80 \\
\hline PI 498805 & Lebanon & 1.50 \\
\hline Mean & & 2.15 \\
\hline \multicolumn{3}{|l|}{ disciformis } \\
\hline PI 487317 & Bulgaria & 2.10 \\
\hline PI 487321 & Greece & 2.85 \\
\hline PI 487322 & Italy & 3.40 \\
\hline PI 487333 & Cyprus & 2.40 \\
\hline Mean & & 2.69 \\
\hline \multicolumn{3}{|l|}{ doliata } \\
\hline PI 495278 & Lebanon & 2.30 \\
\hline PI 505420 & Spain & 1.50 \\
\hline Mean & & 1.90 \\
\hline \multicolumn{3}{|l|}{ doliata var. muricata } \\
\hline PI 534202 & Lebanon & 1.67 \\
\hline PI 534211 & Algeria & 1.50 \\
\hline Mean & & 1.59 \\
\hline \multicolumn{3}{|l|}{ granadensis } \\
\hline PI 498810 & Israel & 3.17 \\
\hline PI 498812 & Turkey & 2.22 \\
\hline PI 498813 & Turkey & 1.66 \\
\hline PI 498817 & Turkey & 2.83 \\
\hline Mean & & 2.47 \\
\hline \multicolumn{3}{|l|}{ heyniana } \\
\hline PI 537136 & Greece & 1.86 \\
\hline \multicolumn{3}{|l|}{ intertexta } \\
\hline PI 498824 & Portugal & 2.42 \\
\hline PI 498828 & Italy & 1.75 \\
\hline PI 516649 & Morocco & 2.33 \\
\hline PI 516650 & Morocco & 2.43 \\
\hline PI 535606 & Tunisia & 2.67 \\
\hline PI 535607 & Tunisia & 2.17 \\
\hline \multirow[t]{2}{*}{ Mean } & & 2.30 \\
\hline & & (continued on next page) \\
\hline
\end{tabular}

a Six-digit numbers are plant introduction (PI) numbers used by the National Plant Germplasm System of the United States Department of Agriculture.

${ }^{b}$ Plants were evaluated for disease severity on a 0-to-5 scale. Data represent the mean of ratings from at least six replicate pots of 10 plants each from two experiments. Plants in each pot were rated on the basis of the lesion type and amount of foliar and stem necrosis and chlorosis, where $0=$ healthy, symptom-free top growth; 1 = small $(<2 \mathrm{~mm})$, brown or black lesions or flecks; no defoliation; $2=$ larger ( 2 to $3 \mathrm{~mm}$ ), discrete lesions; lesions may be on leaves and petioles; usually no chlorosis or defoliation; $3=$ large ( $>3 \mathrm{~mm}$ ) lesions; no defoliation; petiole lesions; $4=$ lesions $>3 \mathrm{~mm}$, chlorosis, dead leaves or defoliation; and $5=$ most of the leaves necrotic or defoliated; dead plant. Least significant difference (1.3) was calculated according to Fisher's protected test at $P \leq 0.05$.

${ }^{\mathrm{c}}$ Standard reference cultivars for spring black stem and leaf spot resistance in $M$ sativa. 
Table 2. (continued from preceding page)

\begin{tabular}{|c|c|c|}
\hline Medicago spp. and PI number ${ }^{a}$ & Country of origin & Disease severity $^{\mathbf{b}}$ \\
\hline \multicolumn{3}{|l|}{ italica } \\
\hline PI 384640 & Morocco & 3.33 \\
\hline PI 385014 & Tunisia & 3.00 \\
\hline PI 459188 & Turkey & 1.67 \\
\hline PI 566864 & Spain & 1.67 \\
\hline PI 566865 & USA Georgia & 1.33 \\
\hline PI 566866 & Italy & 1.33 \\
\hline PI 566867 & Morocco & 1.33 \\
\hline PI 566868 & Sweden & 1.00 \\
\hline Mean & & 1.83 \\
\hline \multicolumn{3}{|l|}{ laciniata } \\
\hline PI 498839 & U.K. & 0.00 \\
\hline PI 498841 & Israel & 1.22 \\
\hline PI 498842 & Czechoslovakia & 0.00 \\
\hline PI 498853 & Spain & 2.00 \\
\hline PI 498864 & Spain & 1.67 \\
\hline PI 498890 & Spain & 2.00 \\
\hline PI 498916 & Morocco & 0.00 \\
\hline PI 498918 & Iraq & 3.00 \\
\hline PI 535738 & Libya & 2.00 \\
\hline Mean & & 1.32 \\
\hline \multicolumn{3}{|l|}{ lanigera } \\
\hline PI 498930 & Former USSR & 4.33 \\
\hline \multicolumn{3}{|l|}{ lesinsii } \\
\hline PI 534233 & Israel & 1.67 \\
\hline PI 537259 & Australia & 1.14 \\
\hline Mean & & 1.41 \\
\hline \multicolumn{3}{|l|}{ littoralis } \\
\hline PI 385006 & Tunisia & 1.83 \\
\hline PI 517206 & Australia & 1.50 \\
\hline PI 537168 & Cyprus & 0.33 \\
\hline PI 537171 & Lebanon & 1.50 \\
\hline PI 537201 & Italy & 0.50 \\
\hline PI 537207 & Spain & 2.67 \\
\hline PI 537222 & Morocco & 0.00 \\
\hline Mean & & 1.19 \\
\hline \multicolumn{3}{|l|}{ lupulina } \\
\hline PI 189128 & Denmark & 1.00 \\
\hline PI 202038 & Argentina & 0.00 \\
\hline PI 215245 & USA Nebraska & 2.00 \\
\hline PI 227452 & Iran & 0.00 \\
\hline PI 234821 & Switzerland & 0.00 \\
\hline PI 251834 & Italy & 0.83 \\
\hline PI 269926 & Pakistan & 2.33 \\
\hline PI 290723 & U.K. & 0.33 \\
\hline PI 304527 & Turkey & 1.50 \\
\hline PI 308059 & Czechoslovakia & 1.50 \\
\hline PI 314538 & Former USSR & 2.00 \\
\hline PI 319026 & Spain & 1.50 \\
\hline PI 452459 & Canada & 0.67 \\
\hline PI 532942 & Nepal & 3.33 \\
\hline PI 566869 & Netherlands & 1.50 \\
\hline Mean & & 1.23 \\
\hline \multicolumn{3}{|l|}{ minima } \\
\hline PI 227032 & Iran & 2.57 \\
\hline PI 499022 & Lebanon & 2.14 \\
\hline PI 499072 & Italy & 1.86 \\
\hline PI 499080 & Turkey & 1.83 \\
\hline Mean & & 2.10 \\
\hline \multicolumn{3}{|l|}{ murex } \\
\hline PI 308062 & Czechoslovakia & 1.50 \\
\hline PI 495350 & Italy & 0.83 \\
\hline PI 495379 & France & 1.00 \\
\hline PI 534231 & Canada & 1.00 \\
\hline PI 516720 & Morocco & 1.17 \\
\hline Mean & & 1.10 \\
\hline \multicolumn{3}{|l|}{ muricoleptis } \\
\hline PI 495401 & Italy & 2.29 \\
\hline \multicolumn{3}{|l|}{ noeana } \\
\hline PI 495407 & Turkey & 3.75 \\
\hline PI 495414 & Unknown & 3.71 \\
\hline \multirow[t]{2}{*}{ Mean } & & 3.73 \\
\hline & & ntinued or \\
\hline
\end{tabular}

genes (4), and to manipulate and enhance resistance to foliar pathogens based on inducible or altered levels of phytoalexins $(4,13,17)$.

There is a need to evaluate populations of annual Medicago spp. for resistance to destructive fungal diseases and to determine whether or not defense expression resistance is based on the production of new or altered levels of fungitoxic flavonoids and isoflavonoids. The objective of the present study was to evaluate resistance to spring black stem and leaf spot in the annual Medicago spp. core collection, and to determine differences in virulence among $P$. medicaginis isolates to a susceptible line of $M$. sativa.

\section{MATERIALS AND METHODS}

Although $P$. medicaginis is not classified by race, isolates obtained from seed vary significantly in virulence to excised $M$. sativa foliage (16). Selection of an isolate for use in screening the annual medic collection, therefore, was based on the ability of the isolate to produce severe disease symptoms in alfalfa. To determine variation in virulence among a collection of diverse isolates and to enable selection of a highly virulent isolate for evaluation of the annual medics, symptom expression of isolates was evaluated on the $M$. sativa susceptible cultivar Ranger (26,30). Inoculum preparation, plant growth conditions, and disease evaluations are as described below for evaluations of the annual Medicago spp. core collection. The virulence of isolates was determined in 10 plants per pot using three pots per isolate, and the experiment was repeated. Data were combined for analysis.

Plants of 200 accessions from 33 species in the annual Medicago spp. core collection were evaluated in growth chambers for resistance to spring black stem and leaf spot caused by $P$. medicaginis. $M$. sativa cvs. Ramsey (moderately resistant) and Ranger (susceptible) were included as standard reference cultivars (30). Plant growth conditions, inoculation, and evaluation of accessions for spring black stem and leaf spot resistance were conducted by a modification of standardized procedures recommended for evaluating this disease in alfalfa $(30,32)$. Seed of each accession were scarified by abrasion against sandpaper and planted in $10-\mathrm{cm}$ pots of a $50 \%$ mixture of pasteurized field soil and Jiffy-Mix Plus (Jiffy Products of America Inc., Batavia, IL) potting mix at a rate of approximately 15 seed per pot. Plants were placed in a growth chamber at $23^{\circ} \mathrm{C}$ with a 16-h fluorescent light photoperiod for 14 days. The number of seedlings per pot was determined 10 days after planting. Those with 10 or more seedlings per pot were inoculated when growth was sufficient for evaluation, generally 2 to 3 weeks after seeding, depending on the species. Plants were spray inoculated to just prior to run-off (approximately $2 \mathrm{ml}$ 
per pot) with a spore suspension of $P$. medicaginis isolate T-431. Pots were incubated in a mist chamber at $23^{\circ} \mathrm{C}$ for $48 \mathrm{~h}$, then returned to a growth chamber for disease development. The relative humidity in the chamber was maintained at $60 \%$, and plants were evaluated for disease reaction 8 to 10 days after inoculation.

Inoculum was prepared by suspending spores of $P$. medicaginis isolate T-431 in sterile distilled water containing Tween 20 at two drops per liter. The inoculum concentration was adjusted to 3 to $4 \times 10^{5}$ spores $/ \mathrm{ml}$. The spore density is less than that which has been used in standard tests ( 1 to $4 \times 10^{6}$ ) because preliminary experiments demonstrated that the lower concentration was sufficient to produce high levels of disease. Spores were obtained from 7-day-old cultures grown on half-strength oatmeal agar (36 $\mathrm{g}$ of Difco oatmeal agar, 1 liter of distilled water, $7.5 \mathrm{~g}$ of agar) at $21^{\circ} \mathrm{C}$ under $12 \mathrm{~h}$ of fluorescent light.

A minimum of 10 seedlings per pot with three replications per accession were evaluated. Some of the accessions exhibited poor germination; therefore, additional sets of pots of these accessions were planted, evaluated, and combined for analysis in the reported experiment. Due to space limitations for inoculation and plant growth chambers, approximately 50 accessions, including the standard cvs. Ramsey and Ranger, were evaluated per run. The experiment was repeated after all lines had been evaluated from the first experiment. The data from at least six pots of 10 plants per pot from the two experiments were combined for analysis. Means for the germ plasm entries were not adjusted based on the disease severity on the standard cultivars.

Disease reactions in the annual medic accessions were evaluated based on class descriptions using a 0 -to-5 scale, designed to account for the lesion size and the amount of defoliation, petiole blight, chlorosis, and necrosis. Gray et al. (16) reported that, in $M$. sativa, ratings for disease should include these symptoms because each appears to play an equally important role in pathogenesis. The rating scale is slightly modified from that described by Salter and Leath (30) for evaluating $M$. sativa resistance to spring black stem and leaf spot. In preliminary experiments, we found that we could distinguish an additional rating class among the annual medic species and take into account additional symptom details. Thus, we deviated from the rating system of Salter and Leath (ratings of 1 to 5) and constructed a rating system to include an additional class (0 to 5). The plants in each pot were rated as follows: $0=$ healthy, symptom-free top growth; $1=$ small $(<2 \mathrm{~mm})$, brown or black lesions or flecks; no defoliation; 2 = larger ( 2 to $3 \mathrm{~mm}$ ), discrete lesions; lesions may be on leaves and petioles; usually no chlorosis or defoliation; 3 = large $(>3 \mathrm{~mm})$ lesions; no defoliation; petiole lesions; 4 = lesions $>3 \mathrm{~mm}$, fruiting; chlorosis, dead leaves, or defoliation; $5=$ most of the leaves necrotic or defoliated; dead plant. According to Salter and Leath (30) alfalfa

plants with scores of 0 to 2 are considered resistant. The expected percentage of alfalfa plants classified as resistant within standard check cvs. Ramsey (moderately

Table 2. (continued from preceding page)

\begin{tabular}{|c|c|c|}
\hline Medicago spp. and PI number ${ }^{a}$ & Country of origin & Disease severity $^{b}$ \\
\hline \multicolumn{3}{|l|}{ orbicularis } \\
\hline PI 210425 & Greece & 1.17 \\
\hline PI 251474 & Turkey & 1.17 \\
\hline PI 283645 & Morocco & 1.50 \\
\hline PI 292421 & Israel & 2.17 \\
\hline PI 505425 & Spain & 1.17 \\
\hline PI 566870 & Romania & 1.00 \\
\hline PI 566871 & Italy & 2.00 \\
\hline PI 566872 & Italy & 1.67 \\
\hline Mean & & 1.48 \\
\hline \multicolumn{3}{|l|}{ polymorpha } \\
\hline PI 478531 & Peru & 1.67 \\
\hline PI 493292 & Portugal & 2.17 \\
\hline PI 493293 & Portugal & 0.83 \\
\hline PI 566873 & Italy & 0.67 \\
\hline PI 566874 & Greece & 1.33 \\
\hline PI 566875 & Cyprus & 1.17 \\
\hline PI 566876 & USA California & 3.67 \\
\hline PI 566877 & Italy & 1.33 \\
\hline PI 566878 & USA Georgia & 3.43 \\
\hline PI 566879 & Germany & 2.83 \\
\hline PI 566880 & Belgium & 1.33 \\
\hline PI 566881 & Lebanon & 4.14 \\
\hline PI 566882 & Greece & 4.00 \\
\hline PI 566883 & France & 4.29 \\
\hline PI 566884 & Syria & 4.14 \\
\hline PI 566885 & Morocco & 3.86 \\
\hline Mean & & 2.55 \\
\hline \multicolumn{3}{|l|}{ polymorpha var. brevispina } \\
\hline PI 186329 & Australia & 3.79 \\
\hline PI 197340 & Australia & 3.00 \\
\hline PI 197530 & Algeria & 2.50 \\
\hline PI 226648 & Iran & 3.33 \\
\hline PI 368949 & Chile & 3.33 \\
\hline PI 385017 & Tunisia & 2.00 \\
\hline Mean & & 2.99 \\
\hline \multicolumn{3}{|l|}{ polymorpha var. polymorpha } \\
\hline PI 206695 & Turkey & 2.50 \\
\hline PI 244312 & Spain & 2.33 \\
\hline PI 250782 & Afghanistan & 2.33 \\
\hline PI 253448 & Yugoslavia & 4.00 \\
\hline PI 283657 & Sweden & 2.00 \\
\hline PI 286534 & Ethiopia & 2.50 \\
\hline PI 292427 & Israel & 1.67 \\
\hline PI 302926 & Spain & 1.67 \\
\hline PI 308055 & Czechoslovakia & 1.50 \\
\hline PI 319036 & Spain & 2.33 \\
\hline PI 404795 & Uruguay & 3.33 \\
\hline PI 459130 & Turkey & 2.50 \\
\hline Mean & & 2.39 \\
\hline \multicolumn{3}{|l|}{ praecox } \\
\hline PI 495429 & Greece & 1.50 \\
\hline PI 495434 & France & 1.67 \\
\hline Mean & & 1.59 \\
\hline \multicolumn{3}{|l|}{ radiata } \\
\hline PI 340800 & Hungary & 3.25 \\
\hline PI 459142 & Turkey & 3.00 \\
\hline PI 459145 & Turkey & 2.25 \\
\hline PI 459146 & Turkey & 2.81 \\
\hline Mean & & 2.83 \\
\hline \multicolumn{3}{|l|}{ rigidula } \\
\hline PI 230350 & Iran & 1.50 \\
\hline PI 233250 & Israel & 1.33 \\
\hline PI 319048 & Spain & 3.75 \\
\hline PI 495517 & Greece & 3.00 \\
\hline PI 534236 & Turkey & 3.25 \\
\hline PI 534250 & Turkey & 4.00 \\
\hline Mean & & 2.81 \\
\hline
\end{tabular}


resistant) and Ranger (susceptible) is 25 and $3 \%$, respectively (30).

The disease reaction data was subjected to analysis of variance with the SAS gen- eral linear models procedure (SAS release 6.11; SAS Institute, Cary, NC). Means were compared using Fisher's protected least significant difference at $P \leq 0.05$.

Table 2. (continued from preceding page)

\begin{tabular}{|c|c|c|}
\hline Medicago spp. and PI number ${ }^{\mathrm{a}}$ & Country of origin & Disease severity $^{b}$ \\
\hline \multicolumn{3}{|l|}{$\overline{\text { rotata }}$} \\
\hline PI 292430 & Israel & 4.33 \\
\hline PI 495576 & Unknown & 4.33 \\
\hline PI 495577 & Italy & 4.75 \\
\hline PI 495583 & Turkey & 4.75 \\
\hline PI 495586 & Lebanon & 3.75 \\
\hline PI 537236 & Czechoslovakia & 4.33 \\
\hline Mean & & 4.37 \\
\hline \multicolumn{3}{|l|}{ rugosa } \\
\hline PI 308061 & Czechoslovakia & 4.00 \\
\hline PI 368962 & Greece & 5.00 \\
\hline PI 442893 & Australia & 3.75 \\
\hline PI 487363 & Portugal & 3.66 \\
\hline PI 487374 & Lebanon & 4.00 \\
\hline PI 487377 & Spain & 4.00 \\
\hline PI 487379 & Italy & 3.75 \\
\hline PI 487382 & Italy & 3.66 \\
\hline PI 487386 & Tunisia & 4.33 \\
\hline PI 535534 & Tunisia & 4.00 \\
\hline PI 535537 & Tunisia & 3.66 \\
\hline Mean & & 3.98 \\
\hline \multicolumn{3}{|l|}{ sauvagei } \\
\hline PI 499152 & Morocco & 5.00 \\
\hline PI 499153 & Unknown & 4.80 \\
\hline Mean & & 4.90 \\
\hline \multicolumn{3}{|l|}{ scutellata } \\
\hline PI 161415 & Uruguay & 3.60 \\
\hline PI 197806 & Australia & 4.00 \\
\hline PI 197817 & USA & 4.20 \\
\hline PI 197821 & Cyprus & 4.50 \\
\hline PI 292432 & Israel & 4.00 \\
\hline PI 487392 & Sweden & 4.50 \\
\hline PI 487393 & Cyprus & 2.80 \\
\hline PI 487394 & Germany & 4.20 \\
\hline PI 487396 & Hungary & 4.20 \\
\hline PI 487403 & Turkey & 3.75 \\
\hline PI 487409 & Lebanon & 4.00 \\
\hline PI 487411 & Italy & 4.20 \\
\hline PI 516907 & Morocco & 4.40 \\
\hline PI 517255 & Ethiopia & 4.33 \\
\hline PI 535643 & Tunisia & 3.60 \\
\hline PI 535644 & Tunisia & 4.50 \\
\hline PI 535645 & Tunisia & 2.80 \\
\hline Mean & & 3.98 \\
\hline \multicolumn{3}{|l|}{ soleirolii } \\
\hline PI 537242 & Algeria & 1.50 \\
\hline PI 537243 & Australia & 1.50 \\
\hline Mean & & 1.50 \\
\hline \multicolumn{3}{|l|}{ tenoreana } \\
\hline PI 499161 & Italy & 1.25 \\
\hline \multicolumn{3}{|l|}{ truncatula } \\
\hline PI 292436 & Israel & 2.25 \\
\hline PI 384648 & Morocco & 3.80 \\
\hline PI 566886 & Italy & 2.80 \\
\hline PI 566887 & Greece & 4.80 \\
\hline PI 566888 & Australia & 4.00 \\
\hline PI 566889 & Turkey & 4.60 \\
\hline PI 566890 & Greece & 3.60 \\
\hline PI 566891 & Czechoslovakia & 4.20 \\
\hline PI 566892 & Spain & 3.60 \\
\hline Mean & & 3.74 \\
\hline \multicolumn{3}{|l|}{ turbinata } \\
\hline PI 441943 & Syria & 2.50 \\
\hline PI 535555 & Tunisia & 2.33 \\
\hline PI 566893 & Lebanon & 2.25 \\
\hline PI 566894 & Turkey & 2.25 \\
\hline PI 566895 & Czechoslovakia & 4.25 \\
\hline Mean & & 2.72 \\
\hline \multicolumn{3}{|l|}{ sativa ${ }^{\mathrm{c}}$} \\
\hline Ramsey (resistant) & USA & 3.60 \\
\hline Ranger (susceptible) & USA & 4.20 \\
\hline
\end{tabular}

\section{RESULTS}

All 19 isolates of $P$. medicaginis produced symptoms of spring black stem and leaf spot on alfalfa cv. Ranger (Table 1). The isolates differed significantly $(P \leq 0.05)$ in the ability to produce symptoms, but the majority produced a moderate level of disease. On a 0-to-5 scale, the range of ratings for symptoms was 2.4 to 4.7 . The experiment was repeated and the results were similar, with each isolate receiving ratings within 1.2 points of the first rating. $P$. medicaginis isolate P1798 (T-431), with a virulence rating of 4.0 on Ranger, was selected for evaluations of lines in the annual Medicago spp. core collection.

Most of the accessions in the annual Medicago spp. core collection were susceptible to spring black stem and leaf spot (Table 2). Species with highly susceptible accessions included $M$. arabica, $M$. lanigera, M. minima, M. rotata, M. rugosa, $M$. sauvagei, and $M$. scutellata. Ten species whose accessions exhibited high resistance included $M$. constricta, $M$. doliata, $M$. heyniana, M. laciniata, M. lesinsii, M. murex, M. orbicularis, M. praecox, M. soleirolii, and $M$. tenoreana. Accessions of $M$. murex exhibited the highest level of resistance, with a mean disease rating of 1.1. Several accessions within $M$. laciniata and $M$. lupulina were highly resistant, with ratings of 0.0 .

The degree of susceptibility found among accessions within species was variable. Within one of the more susceptible species, M. polymorpha, ratings ranged from 0.67 (PI 566873) to 4.29 (PI 566883). Most of the $M$. truncatula accessions were significantly more susceptible than accessions of other species. Disease ratings of the check cultivars of $M$. sativa ranged from 3.5 to 4.5 in Ranger and 3.0 to 4.0 in Ramsey.

\section{DISCUSSION}

The wide range of reactions expressed within and among accessions suggests that the medics harbor diverse sources of resistance to spring black stem and leaf spot. The significant range in susceptibility to $P$. medicaginis within accessions was not unexpected. Our results are consistent with results from field evaluations of annual Medicago spp. in South Africa (2). In particular, with few exceptions, their results revealed that the cultivars of $M$. truncatula and $M$. polymorpha that were tested were highly susceptible but included a range of disease reactions. In South African field studies, among 42 lines tested from five species, $M$. murex was found to have the most resistance (2). This species also was one of the most resistant in our tests with $P$. medicaginis, and also was reported to be highly resistant to anthracnose disease caused by Colletotrichum trifolii (26).

Only one highly virulent isolate of $P$. medicaginis was used to evaluate the resistance in the study reported here, and reactions to other strains of the pathogen may 
vary. The strains evaluated for virulence in this study ranged in disease ratings from 2.4 to 4.7 on cv. Ranger (Table 1). Characterization of the population structure of $P$. medicaginis and related species has not yet been elucidated, and the degree of pathogenic and genetic variation that exists within alfalfa-infecting isolates from different geographical regions is unknown. These components will be important for understanding the biology of the fungus and for the development of effective methods to control disease. According to Salter and Leath, approximately 75 to $80 \%$ of the plants of cv. Ramsey and $97 \%$ of cv. Ranger were expected to be susceptible to the disease, which they described as moderately resistant and susceptible, respectively (30). In our test, Ramsey was not significantly different from Ranger. The selection of a highly virulent isolate, in conjunction with experimental conditions highly conducive to severe disease development, resulted in severe disease symptoms and ratings on Ranger as well as Ramsey (Table 2).

Accessions and cultivars of both annual and perennial Medicago spp. exhibit a wide range of disease reactions to diseases, including $P$. medicaginis, Erysiphe pisi, and $C$. trifolii $(25,26,28,36)$. Phoma and Colletotrichum resistance are inherited characters in alfalfa $(14,28)$; therefore, disease resistance traits could be utilized in a medic breeding program to increase the level of resistance to anthracnose and spring black stem and leaf spot available in commercial cultivars. It would be interesting to screen the world annual Medicago spp. core collection (31) located in Adelaide, South Australia, Australia (South Australian Research and Development Institute, Genetic Resources Collection) for resistance to these diseases. The Australian collection is composed of over 24,000 accessions and the core collection contains 1,705 accessions.

Resistance to major diseases in alfalfa increases quality, yield, and adaptability. Traditional methods of breeding alfalfa for resistance are limited by the autotetraploid nature of alfalfa and the severe effects of inbreeding depression. Annual Medicago spp. may be a source of resistance via new or different toxic secondary metabolites that suppress the pathogen and disease. An advantage to using annual medics is that they are simpler genetically to study and manipulate than perennial alfalfa. Resistance is the most desirable type of control for alfalfa pathogens because of the large acreage grown and the perennial character of the crop. Resistance to diseases caused by highly pathogenic foliar pathogens in alfalfa currently is needed, and new sources of disease-resistance genes should result from the identification of disease resistant accessions of annual Medicago spp. germ plasm. Such genes may facilitate the development of genetically engineered plants with broad spectrum disease resistance.

\section{LITERATURE CITED}

1. Barbetti, M. J. 1995. Relative resistance, associated yield losses, and phyto-oestrogen production from fungal foliar diseases in new and old annual Medicago cultivars. Aust. J. Agric. Res. 46:441-450.

2. Barbetti, M. J. 1995. Resistance in annual Medicago species to Phoma medicaginis and Leptosphaerulina trifolii under field conditions. Aust. J. Exp. Agric. 35:209-214.

3. Barbetti, M. J., and Nichols, P. G. H. 1991. Effect of Phoma medicaginis and Leptosphaerulina trifolii on herbage and seed yield and coumesterol content of annual Medicago species. Phytophylactica 23:223-227.

4. Barker, D. G., Bianchi, S., Blondon, F., Dattée, Y., Duc, G., Essad, D., Flament, P., Gallusci, P., Génier, G., Guy, P., Muel, X., Tourneur, J., Dénarié, J., and Huguet, T. 1990. Medicago truncatula, a model plant for studying the molecular genetics of the Rhizobium-legume symbiosis. Plant Mol. Biol. Rep. 8:40-49.

5. Bauchan, G. R. 1998. What are annual medics? Page 2 in: Proc. North Am. Alfalfa Improv. Conf., 36th. Boseman, MT. J. Bouton and G. R. Bauchan, eds. North Am. Alfalfa Improv. Conf., Beltsville, MD.

6. Bell, C. J., Dixon, R. A., Farmer, A. D., Flores, R., Inman, J. Gonzales, R. A., Harrison, M. J. Paiva, N. L. Scott, A. D., Weller, J. W., and May, G. D. 2001. The Medicago genome initiative: a model legume database. Nucleic Acids Res. 29:114-117.

7. Chabaud, M., Larsonneau, C., Marmouget, C., and Huguet, T. 1996. Transformation of barrel medic (Medicago truncatula Gaertn.) by Agrobacterium tumefaciens and regeneration via somatic embryogenesis of transgenic plants with the MtENOD12 nodulin promoter fused to the gus reporter gene. Plant Cell Rep. 15:305-310.

8. Cook, D. R. 1999. Medicago truncatula-a model in the making? Curr. Opin. Plant Biol. 8:301-304.

9. De Haan, R. L., Sheaffer, C. C., and Samac, D. A. 1996. First report of Phytophthora medicaginis causing Phytophthora root rot on annual medics (Medicago spp.). Plant Dis. 80:710.

10. Diwan, N., Bauchan, G. R., and McIntosh, M. S. 1994. A core collection for the United States annual Medicago germplasm collection. Crop Sci. 34:279-285.

11. Diwan, N., McIntosh, M. S., and Bauchan, G. R. 1994. Evaluation of the annual medic core collection across the U.S. Page 13 in: Proc. North Am. Alfalfa Improv. Conf., Univ. Guelph, Ontario, Canada.

12. Diwan, N., McIntosh, M. S., and Bauchan, G. R. 1995. Methods of developing a core collection of annual Medicago species. Theor. Appl. Genet. 90:755-761.

13. Dixon, R. A., Paiva, N. L., and Bhattacharyya, M. K. 1993. Engineering disease resistance in plants: an overview. In: Advanced Methods in Plant Pathology. R. P. Singh and U. S. Singh, eds. CRC Press, Boca Raton, FL.

14. Elgin. J. H., Jr., and O'Neill, N. R. 1988. Comparison of genes controlling race 1 anthracnose resistance in Arc and Saranac AR alfalfa. Crop Sci. 28: 657-659.

15. Fisk, J. W., Hesterman, O. B., Shrestha, A., Kells, J. J., Harwood, R. R., Squire, J. M., and Sheaffer, C. C. 2001. Weed suppression by annual legume cover crops in no-tillage corn. Agron. J. 93:319-325.

16. Gray, F. A., Fernandez, J. A., and Horton, J. L. 1990. Variation among isolates of Phoma medicaginis var. medicaginis in spore production in vitro and symptom expression on excised leaves of alfalfa. Plant Dis. 74:668-670.

17. Harrison, M. J., and Dixon, R. A. 1993. Isoflavonoid accumulation and expression of defense gene transcripts during the establishment of vesicular-arbuscular mycorrhizal association in roots of Medicago truncatula. Mol. Plant-Microbe Interact. 6:643-654.

18. He, X.-Z., and Dixon, R. A. 2000. Genetic manipulation of isoflavone 7-O-methyltransferase enhances biosynthesis of 4'-O-methylated isoflavonoid phytoalexins and disease resistance in alfalfa. Plant Cell 12:1689-1702.

19. Higgins, V. J. 1972. Role of the phytoalexin medicarpin in three leaf spot diseases of alfalfa. Physiol. Plant Pathol. 2:289-300.

20. Hipskind, J. D., and Paiva, N. L. 2000 Constitutive accumulation of a resveratrolglucoside in transgenic alfalfa increases resistance to Phoma medicaginis. Mol. PlantMicrobe Interact. 13:551-562.

21. Hollingsworth, C. R., and Gray, F. A. 1999. First report of brown root rot on alfalfa caused by Phoma sclerotioides in the continental United States. Plant Dis. 83:1071.

22. Ingham, L. 1979. Isoflavonoid phytoalexins in the genus Medicago. Biochem. Syst. Evol. 7:29-34.

23. Lamprecht, S. C. 1986. Reaction of annual Medicago species to Colletotrichum crown rot caused by Colletotrichum trifolii. Phytophylactica 18:183-185.

24. Lamprecht, S. C., and Knox-Davies, P. S. 1984. Preliminary survey of foliage diseases of annual Medicago spp. in South Africa. Phytophylactica 16:177-183.

25. O'Neill, N. R. 1996. Pathogenic variability and host resistance in the Colletotrichum trifolii/Medicago sativa pathosystem. Plant Dis. 80:450-457.

26. O'Neill, N. R., and Bauchan, G. R. 2000 Sources of resistance to anthracnose in the annual Medicago core collection. Plant Dis. 84:261-267.

27. Paiva, N. L., Oommen, A., Harrison, M. J., and Dixon, R. A. 1994. Regulation of isoflavonoid metabolism in alfalfa. Plant Cell Tissue Organ Cult. 38:213-220.

28. Rhodes, L. H., and Myers, D. K. 1986. Severity of Spring black stem on alfalfa cultivars in Ohio. Plant Dis. 70:746-748.

29. Rizvi, S. S. A., and Nutter, F. W., Jr. 1993. Seasonal dynamics of alfalfa foliar pathogens in Iowa. Plant Dis. 77:1126-1135.

30. Salter, R. M., and Leath, K. L. 1992. Spring black stem and leafspot resistance. Section D11 in: Standard Tests to Characterize Alfalfa Cultivars. 3rd ed. C. C. Fox, R. Berberet, F. A. Gray, C. R. Grau, D. L. Jessen, and M. A. Peterson, eds. North American Alfalfa Improvement Conference, Beltsville, MD.

31. Skinner, D. Z., Bauchan, G. R., Auricht, G., and Hughes, S. 1999. A method for the efficient management and utilization of large germplasm collections. Crop Sci. 39:1237-1242.

32. Stuteville, D. L., and Erwin, D. C. 1990 Compendium of Alfalfa Diseases, 2nd ed. American Phytopathological Society Press, St. Paul, MN

33. Wang, J. H., Rose, R. J., and Donaldson, B. I 1996. Agrobacterium-mediated transformation and expression of foreign genes in Medicago truncatula. Aust. J. Plant Physiol. 23:265-270.

34. Wilcoxson, R. D., Bielenberg, O., and Bissonette, H. L. 1973. Yield of alfalfa hay increased by control of foliar diseases. Plant Dis. Rep. 57:353-354.

35. Yaege, J. R., and Stuteville, D. L. 2000. Reactions in the annual Medicago core germ plasm collection to two isolates of Peronospora trifoliorum from alfalfa. Plant Dis. 84:521524.

36. Yaege, J. R., and Stuteville, D. L. 2002. Reactions of accessions in the annual Medicago core germ plasm collection to Erysiphe pisi. Plant Dis. 86:312-315. 